\title{
Facilitative glucose transporters in ruminants
}

\author{
BY JEAN-FRANÇOIS HOCQUETTE ${ }^{1}$ AND MICHELE BALAGE \\ ${ }^{1}$ Laboratoire Croissance et Métabolismes des Herbivores et ${ }^{2}$ Laboratoire d'Etude du Métabolisme \\ Azoté, INRA, Theix, 63122 Saint-Genès Champanelle, France
}

AND PASCAL FERRÉ

INSERM U342, Hôpital Saint Vincent de Paul, 75014 Paris, France

\section{Les transporteurs du glucose à diffusion facilitée chez les ruminants}

\section{RÉSUMÉ}

L'étude des transporteurs du glucose à diffusion facilitée (GLUT) chez les ruminants est difficile en raison du peu d'outils (anticorps, sondes) spécifiques des espèces concernées. Néanmoins, certaines particularités des ruminants ont pu être mises en evidence. Comme chez les autres espèces, le transport du glucose dans le tissu musculaire de bovin est une étape limitante de son métabolisme; de plus, ce transport est sensible à l'insuline car assuré principalement par le transporteur insulino-sensible GLUT4. Cependant, contrairement aux observations chez le rat et l'homme, la quantité de GLUT4 est plus importante dans les muscles glycolytiques que dans les muscles oxydatifs chez le bovin et la chèvre bien que la quantité d'ARNm de GLU'T4 tende à être plus élevée dans les muscles oxydatifs. L'intensité du transport du glucose dans le muscle est plus importante chez le bovin 'culard' présentant une hypertrophie musculaire que chez le bovin normal soulignant ainsi l'importance du métabolisme du glucose pour la croissance. L'intensité du transport du glucose in vitro augmente dans le muscle chez le veau au sevrage alors que le nombre de GLUT4 ne varie pas dans les tissus musculaires et adipeux contrairement aux données chez le rat. En revanche, le nombre de GLUT4 dans les muscles diminue chez la chèvre en début de lactation expliquant ainsi la diminution de la sensibilité à l'insuline préalablement observée in vivo. Le clonage récent de l'ADNc de GLUT4 de bovin devrait permettre d'approfondir la régulation de l'expression de ce transporteur. Les intensités de la glycolyse et du transport du glucose dans les hépatocytes et les érythrocytes sont plus faibles chez le bovin que chez le chien, le rat ou l'homme, ce dernier résultat s'expliquant par une très faible expression de GLUT1 dans les globules rouges de bovin. L'expression des gènes de GLUT3, et surtout de GLUT5, est différente entre le bovin et l'homme: en effet, des ARNm codant pour GLUT5 ont été détectés dans le foie de vache sans que l'on en connaisse la signification physiologique. La culture in vitro des cellules vasculaires et rétiniennes de bovin sert de modèle pour étudier la régulation de l'expression de GLUT1 et de GLUT3 par l'hyperglycémie afin d'analyser les mécanismes à l'origine des rétinopathies et des maladies vasculaires associées au diabète. La régulation de l'expression de GLUT1 dans les cellules endothéliales de cerveau de bovin en culture est également très étudiée. Les caractéristiques de GLUT1 dans le cerveau (distribution cellulaire, niveau d'expression, poids moléculaire) ne sont pas différentes entre le bovin et les monogastriques. L'ADNc de GLUT1 de bovin a été cloné et suggère une conformation particulière de la protéine 
dans sa partie $\mathrm{N}$-terminale, dont les conséquences physiologiques ne sont pas connues. D'autres transporteurs importants pour la régulation du métabolisme du glucose tels que GLUT2 dans le foie et le pancréas restent à étudier.

The characteristic features of digestion and energy metabolism of ruminants come from fermentation of food in the reticulo-rumen, which harbours micro-organisms capable of digesting fibrous material such as cellulose. This enables ruminants to eat and partly digest plants. The principal products of fermentation of dietary carbohydrate are short-chain fatty acids, mainly acetate, propionate and butyrate. As a consequence of the low dietary absorption of glucose, blood glucose level is approximately $30 \%$ lower in ruminants than in humans, and the ruminant has somewhat adapted the regulation of its glucose metabolism (for review, see Brockman, 1993). The present review focuses on the mechanisms of this adaptation at the level of facilitative glucose transporters. These transporters can be divided into two families: insulin-sensitive (GLUT4) and non-insulinsensitive (GLUT 1, 2, 3 and 5) glucose transporters in both single-stomached and ruminant mammals. Attempts have been made to use the available reagents (antibodies against rat glucose transporters, human or rat probes) to analyse glucose-transporter expression in ruminants, but it has not always been possible (Schultz et al. 1992; Hocquette et al. 1996a) because of the lack of homology between DNA or amino acid sequences among species and/or the low concentrations of glucose transporters in tissues. This may explain the difficulty in studying facilitative glucose transporters in ruminants and, consequently, the relatively small amount of data in this area. However, some quantitative or qualitative differences in expression of glucose transporters have been shown between ruminants and non-ruminants.

\section{GLUCOSE TRANSPORTERS IN INSULIN-SENSITIVE TISSUES}

Insulin is basically able to stimulate glucose transport and metabolism in both adipose and muscle tissues. Since brain and liver use larger amounts of glucose in human subjects than in ruminants, the proportion of total glucose flux utilized by the muscle mass is more important in sheep (40-50\%) than in humans $(10-15 \%)$. By contrast, adipose tissue in the ruminant represents only a minor fate of glucose disposal, accounting for about $1 \%$ of total glucose utilization (for review, see Pethick, 1984). Therefore, attention has been focused on the glucose transporter-insulin system in muscle from ruminants.

\section{Glucose transport in insulin-responsive tissues}

The fact that glucose transport is a rate-limiting step for glucose utilization by muscle and adipose tissue in rats has been extensively documented using different approaches (Elbrink \& Bihler, 1975; Ziel et al. 1988; Ren et al. 1993) which are too difficult and expensive to apply to large species such as sheep or cattle. Nevertheless, it has been shown that bovine muscle tissue (as reflected by the hindlimb) extracts only $3 \%$ of the blood glucose passing through, whereas sheep adipose tissue (as reflected by the tail fat pad) extracts about $10 \%$ of the glucose presented to it (for review, see Brockman, 1993). These fractional extraction rates appear to be low in comparison with those of other 
energy-yielding substrates (for example, $36 \%$ for acetate; Prior et al. 1984). This suggests a strong rate-limiting step for glucose uptake in vivo. In our laboratory, we measured glucose transport rate in incubated fibre strips of bovine muscle as previously performed on human muscle tissue (Dohm et al. 1988). This technique enabled us to conclude that, as in rat muscle, hexokinase (EC 2.7.1.1) activity is higher than glucose transport rate, providing evidence that glucose transport is a rate-limiting step for glucose utilization by the bovine muscle.

In vivo studies showed that insulin increases glucose utilization by muscles and adipose tissues as much as 5-fold at very high concentrations (for review, see Brockman, 1993). However, a comparison of euglycaemic hyperinsulinaemic clamp studies in human subjects (Rizza et al. 1981), rats (Burnol et al. 1986) and growing or adult ruminants (sheep: Brockman \& Laarveld, 1986; goats: Debras et al. 1989; cows: Sano et al. 1991; calves: Hostettler-Allen et al. 1994) revealed lower insulin responsiveness of peripheral tissues in ruminants: maximally insulin-stimulated glucose utilization rates (in $\mathrm{ml} / \mathrm{min}$ per $\mathrm{kg}$ ) for sheep, goats or bovines were $50-75$ and $15-25 \%$ of the rates for human subjects and rats respectively. Moreover, in vitro studies showed that insulin stimulates glucose transport rate in muscles to a greater extent in human subjects $(+123 \%$; Dohm et al. $1988)$ and rats $(+258 \%)$ than in calves (+82\%; Hocquette et al. 1995). The ability of insulin to stimulate glucose transport rate in isolated adipocytes is also lower in sheep $(+120-170 \%)$ than in rats (+ approximately $500 \%$; Sasaki, 1990) or in human subjects ( $+300 \%$; for review, see Garvey, 1994). Therefore, it is not unreasonable to speculate that there are differences in the insulin-glucose transporter system among species since a correlation between GLUT4 levels and insulin responsiveness has been reported in rat and human muscles (Henriksen et al. 1990; Garvey, 1994).

\section{Glucose transporter isoform distribution in insulin-sensitive tissues}

A GLUT4-like protein was first detected in goat adipose tissue (Trayhurn et al. 1993) and bovine skeletal muscle (Mandarino et al. 1994) by immunoblot analysis with an antibody against rat GLUT4. More recently, we studied the tissue distribution of GLUT4 in crude membranes from bovine and goat tissues (Hocquette et al. 1995) using a polyclonal antibody against rat GLUT4 (James et al. 1989). This insulin-sensitive glucose transporter was detected in all insulin-responsive tissues (heart, skeletal muscles, adipose tissues) from calves and goats but not in other tissues (liver, intestine, brain, erythrocytes; Hocquette et al. 1995). Moreover, GLUT4 mRNA was present in heart, muscles and adipose tissues but not in non-insulin-responsive tissues from calves (Hocquette et al. 1996b) and cows (Zhao et al, 1993). GLUT1 protein was detected in bovine heart (Wheeler \& Hauck, 1985). However, the low abundance of GLUT1 and GLUT3 mRNA in muscles compared with GLUT4 mRNA and the absence of any detectable mRNA for the other glucose transporters (Zhao et al. 1993) suggest that GLUT4 is the major glucose transporter isoform in these tissues as in other species (for review, see Gould \& Holman, 1993). A similar conclusion can be made for adipose tissues (Hocquette et al. 1996b).

GLUT4 content was quantified in Triton extracts from various bovine and goat muscles by immunoblotting (Hocquette et al. 1995) using the same polyclonal antibody against rat GLUT4 (James et al. 1989) and two different systems of detection ( ${ }^{125} \mathrm{I}$ - 
labelled protein $\mathrm{A}$ and a chemiluminescent reaction). Whereas in rats, it has been widely demonstrated that heart and oxidative muscles contain more GLUT4 than glycolytic muscles (James et al. 1989; Henriksen et al. 1990), we showed that in calves and goats, GLUT4 content was lower in heart, masseter and diaphragma (the most oxidative muscles) than in other skeletal muscles (Hocquette et al. 1995). However, the use of another antibody against rat GLUT4 on whole-muscle homogenates from cattle did not confirm our results (Abe et al. 1994). This may be explained by the lower specificity of the antibody used in this latter study, although this antibody did detect bovine GLUT4 in crude membranes in some but not all experiments. Moreover, non-specific bands may appear in crude homogenates but not in membrane preparations, especially with non-radioactive systems of revelation (Hocquette et al. 1996a). Finally, one possible mechanism for the selective detection of GLUT4 in glycolytic muscles by one antibody but not the other may be the tissue-specific glycosylation of the GLUT4 protein: indeed, bovine adipose tissue, heart and skeletal muscle GLUT4 proteins seem to be subject to differential glycosylation (J. F. Hocquette and C. Castiglia-Delavaud, unpublished results). However, in agreement with our results at the protein level, glucose transport rate in rectus abdominis muscle is positively related to glycolytic rather than to oxidative characteristics of the studied muscle in normal and double-muscled calves, the latter being characterized by muscle hypertrophy and a higher proportion of glycolytic muscle fibres (Picard et al. 1994). In contrast, in human muscle, insulin-stimulated glucose transport rate in vitro and GLUT4 protein are positively correlated with the proportion of oxidative muscle fibres (Hickey et al. 1995).

All these data on GLUT4 content and activity suggest species-specific control mechanisms of GLUT4 expression in muscles. These differences between singlestomached animals and ruminants need to be confirmed by other approaches such as measurements of in vivo glucose transport rate in various muscles, or the use in immunoblotting of a specific antibody against bovine GLUT4. We speculated that the low GLUT4 content in oxidative muscles from ruminants should limit glucose uptake and utilization by these muscles and, therefore, spare glucose for the benefit of tissues, such as brain and glycolytic muscles, that are obligatory glucose utilizers. This limited glucose-transport capacity suggests that oxidative muscles may use acetate (the arterial concentration of which is high in the ruminant) rather than glucose which comes mainly from the gluconeogenic process. Moreover, it can be hypothesized that the overall decreased responsiveness of glucose metabolism and glucose transport to insulin in ruminant species could be explained, at least in part, by the low content of GLUT4 in oxidative muscles and oxidative fibres from different muscles (Hocquette et al. 1995).

More recently, we showed that GLUT4 content was higher in omental, perirenal and intermuscular adipose tissues than in subcutaneous adipose tissue from calves (Hocquette et al. 1996) whatever the antibody used (J. F. Hocquette and C. CastigliaDelavaud, unpublished results). This may be related to the lower metabolic activity of this latter tissue (Vernon et al. 1987) and to the low insulin responsiveness of glucose transport in adipocytes from subcutaneous adipose tissue (Sasaki, 1990).

\section{GLUT4 gene expression in bovine muscles}

The lack of previous studies on the regulation of GLUT4 expression in ruminants results in part from the lack of a homologous probe. However, cDNA for human glucose 
transporters have been used to determine the distribution of these transporters in bovine tissues using riboprobes (Zhao et al. 1993); GLUT4 mRNA was barely detectable because of the presence of a high background and a non-specific band. This prompted us to clone a bovine GLUT4 cDNA fragment. The nucleotide sequence of our polymerasechain-reaction-amplified DNA fragment was quite similar to related sequences of GLUT4 in rats, human subjects and pigs (Hocquette et al. 1996b). Moreover, as in rats (James et al. 1989), this cDNA fragment hybridizes to a single transcript of 2.8 kilobases only in total RNA from bovine insulin-sensitive tissues. More recently, the full bovine GLUT4 cDNA was cloned. It is composed of 2676 base pairs and encodes for a 509 amino acid protein. The deduced amino acid sequence was $64 \%$ homologous to that of bovine GLUT1 and 94\% homologous to that of rat GLUT4 (Abe et al. 1995).

Amounts of GLUT4 mRNA tend to be higher in oxidative muscles than in other skeletal muscles in the calf. Thus, the discrepancy between amounts of GLUT4 protein and GLUT4 mRNA indicates that translational and/or post-translational control mechanisms (i.e., at the protein translational or degradation levels respectively) are involved in GLUT4 protein expression in muscles (Hocquette et al. 1996b). GLUT4 protein and mRNA appear generally to be unrelated in skeletal muscle unlike in adipose tissues (for review, see Klip et al. 1994), although a positive correlation was found between amounts of GLUT4 mRNA and GLUT4 protein in various rat skeletal muscles except heart (Henriksen et al. 1990). This suggests that the GLUT4 protein expression may be controlled by various mechanisms including RNA and protein turnovers and translation efficiency. The relative importance of these control mechanisms may be subject to variations among muscles (oxidative $v$. glycolytic) or among species (singlestomached animals $v$. ruminants), translational and/or post-translational mechanisms probably being important in bovines. Therefore, a thorough investigation of the rates of glucose transporter synthesis and half-life is necessary.

\section{Regulation of GLUT4 activity and expression}

Weaning. Extensive metabolic adaptations induced by profound changes in nutrition occur at weaning as calves develop from the non-ruminating to the ruminating state; carbohydrate and fat (present in milk substitutes and whole milk) provide $30-45$ and $35-50 \%$ of metabolizable energy intake respectively for the young calf and less than $10 \%$ each for the weaned calf. These changes induce a decrease by over 200 -fold of the $\mathrm{Na}^{+}$-glucose transporter (SGLT1) activity and abundance in intestinal brush-border membranes. At the same time, SGLT1 mRNA levels decrease only 4-fold suggesting translational and/or post-translational control mechanisms of bovine SGLT1 expression (Lescale-Matys et al. 1993). More recently facilitative transporters have been studied in peripheral tissues during the suckling-weaning transition. Muscle samples were taken from age-matched preruminant and ruminant calves. Glucose transport rate was measured in vitro in rectus abdominis muscle fibre strips with identical glucose and insulin concentrations in the incubation medium. Basal and maximally insulin-stimulated glucose transport rates were higher in muscles from weaned calves. However, this increase in glucose utilization potential at weaning is probably counter-balanced in vivo by the lower glucose and insulin blood levels in weaned calves (Roehrig et al. 1988), so that the total glucose utilization by muscles may not change. Preliminary results suggest 
that the GLUT4 content does not change at weaning in muscles (Hocquette et al. 1994) and adipose tissues (J. F. Hocquette and C. Castiglia-Delavaud, unpublished results).

The changes in nutrition which occur at weaning differ between rats and bovines, and, consequently, the metabolic adaptations induced by weaning are also different between these two species. In rats, weaning induces a shift from a fat-rich diet (milk) to a carbohydrate-rich diet leading to an increase in insulin blood levels. This is associated with an increase in insulin responsiveness of glucose transport and an enhanced expression of GLUT4 in muscles and adipose tissues in contrast to the situation in bovines (for review, see Girard et al. 1992).

Our results in vitro demonstrating a low insulin responsiveness in the muscle in the preruminant calf are in agreement with those in vivo demonstrating that calves which are intensively fed with milk substitutes for veal production develop insulin resistance, hyperglycaemia and glucosuria (Hostettler-Allen et al. 1994); therefore, prevention of these abnormalities would be expected to increase glucose use as an energy source, and to improve feed conversion and growth parameters. It has been shown that insulin resistance appears to limit the rate of weight gain in obese human subjects (Swinburn et al. 1991). The insulin resistance of calves was exaggerated after milk consumption, providing evidence for the involvement of nutritional factors (Hostettler-Allen et al. 1994). Recent data suggest that lactose content in milk might be responsible for the development of the low insulin responsiveness (Hugi \& Blum, 1994). The regulation of GLUT4 activity and expression by lactose is still unknown.

Exercise. It is well known that acute exercise leads to an increase in glucose transport rate by translocation of GLUT4. This mechanism remains to be demonstrated in ruminants, but is likely to be the same in all species. However, high rates of exercise result in significant hypoglycaemia in human subjects but hyperglycaemia in sheep because of high hepatic glucose output (for review, see Pethick, 1993). A probable benefit of this hyperglycaemia would be to facilitate concentration-dependent glucose uptake by working muscles and, therefore, to compensate for the low amount of GLUT4 available in oxidative muscles from ruminants during exercise.

Lactation. In vivo studies showed that lactation in goats is associated with an impairment in the ability of insulin to maximally stimulate glucose utilization (Debras et al. 1989). In contrast, basal and insulin-stimulated glucose turnovers are enhanced in lactating rats (Burnol et al. 1986). Previous studies clearly indicated that the insulin resistance in goats originated from a post-receptor defect (Balage et al. 1992). Lactation resulted in a $25-50 \%$ decrease in GLUT4 protein content in both crude membranes and homogenates from goat muscles, which is consistent with the $50 \%$ decrease in the maximally-stimulated insulin response of whole-body glucose utilization (Balage et al. 1994). This impairment in glucose disposal in skeletal muscles may spare glucose for the benefit of the mammary gland, a high-glucose-consuming organ in lactating animals. GLUT1 gene expression is high in mammary glands in lactating cows (Zhao et al. 1993). The origin of the decrease in GLUT4 protein content in skeletal muscles from lactating goats is still unknown but might be related to a down-regulation of GLUT4 synthesis by growth hormone, the blood level of which increases in early-lactating animals.

Growth. The efficiency with which ingested protein is used for growth in ruminants is lower with forage diets (high-fibre diets leading to a high proportion of acetate) compared with concentrate diets (high-starch diet leading to a high production of 
propionate which is a glucose precursor). Recent findings from our group confirm the idea that glucose is efficient for muscle growth. Glucose transport rate was measured in incubated rectus abdominis muscle fibre strips from normal calves and double-muscled calves, the latter being characterized by a muscle hypertrophy of genetic origin. Basal and maximally insulin-stimulated glucose transport rates were positively correlated with the weight of rectus abdominis muscle and to growth variables (Picard et al. 1994). These results are consistent with those in human subjects, demonstrating that weight gain was positively correlated with glucose disposal at submaximally- and maximally-stimulating insulin concentrations (Swinburn et al. 1991).

A fall in intramuscular $\mathrm{pH}$ due to glycogenolysis occurs after slaughter during conversion of muscles into meat. In cattle, glycogen deficiency at slaughter results in dark-cutting because the ultimate $\mathrm{pH}$ is too high, thereby affecting meat quality. This problem is of commercial importance in major beef-producing countries. Dark-cutting is considered to result from glycogen mobilization in muscle by exposure of the animals to various forms of stress (mixed penning, transport, waiting before slaughter) and to a possible slow rate of glycogen recovery during resting periods (McVeigh \& Tarrant, 1982). The latter may be related to a defect in the glucose transport system, the rate-limiting step of glucose metabolism. This remains to be studied.

\section{Genetic manipulation of glucose-transporter expression}

Transfer of genes for improved animal productivity traits has become an active area of investigation (Pursel \& Rexroad, 1993). Studies have been carried out to overexpress GLUT1 (Ren et al. 1993; Gulve et al. 1994) or GLUT4 (Liu et al. 1992, 1993) genes in mice. The tissue-specific expression of GLUT4 as well as the hormonal and metabolic regulation of GLUT4 were reproduced (Liu et al. 1992; Olson et al. 1993). The overexpression of GLUT4 or GLUT1 induced an increase in basal glucose uptake, a marked reduction in blood glucose levels, an increase in muscle glycogen content and a defective response to diverse stimuli (insulin, IGF-1, contractions) that activate GLUT4mediated glucose transport rate (Liu et al. 1993; Ren et al. 1993; Gulve et al. 1994). However, no difference in total body weight and rates of growth were observed (Liu et al. 1993). Nevertheless, overexpression of GLUT4 in growing farm animals would probably modify meat characteristics because of higher levels of glycogen in muscles.

Other studies examined the feasibility of using anti-sense oligonucleotides to reduce bovine GLUT1 expression by cells in vitro or by organ in vivo. Bovine GLUT1 was used as a model to understand the biological mechanisms which may induce glucose deprivation to cancer cells (which overexpress GLUT1) and, therefore, inhibit cell division. The technology used was based on a complete protection of the anti-sense oligonucleotides against serum nuclease degradation by an avidin-biotin system (Boado \& Pardridge, 1992). This type of technology could be applied to reduce GLUT1 or GLUT4 expression in adipose tissue, and consequently, fat deposition. However, the results of such experiments are doubtful in ruminants since preliminary results suggest that the lower total adipose tissue weight in double-muscled calves compared with normal ones was not associated with any difference in the amount of GLUT4 (J. F. Hocquette and C. Castiglia-Delavaud, unpublished results). 


\section{GLUCOSE TRANSPORTERS IN NON-INSULIN-SENSITIVE TISSUES}

Nutrients are supplied to tissue cells via a network of blood vessels. The walls of these vessels are in most cases permeable, which facilitates the exchange of substances. Studies using single-stomached mammals showed that some specific glucose transporters located in the membranes of the tissue cells mediate glucose uptake (GLUT2 in hepatocytes, GLUT4 in adipocytes and muscle cells, GLUT1 in erythrocytes). The maximal transport capacity of glucose is related to the amounts of glucose transporters in the plasma membranes of the cells. In contrast, impermeable vascular barriers are found in the brain (blood-brain barrier) and the eye (blood-ocular barrier). In some cases (brain), the endothelial cells of the capillaries are impermeable and glucose is carried out by specific transporters (GLUT1, GLUT3) located at both luminal and contraluminal plasma membranes of the endothelial cells. In other cases (retina), capillaries are fenestrated and therefore permeable, but epithelial cells surrounding the tissues are impermeable. Specific glucose transporters (GLUT1) were found at both the apical and the basolateral membranes of the epithelial cells from single-stomached animals (for review, see Takata et al. 1993).

\section{Digestive tract}

Although ruminants eat large amounts of carbohydrate consisting mainly of cellulose and hemicellulose, these polymers are degraded in the rumen. Consequently, ruminants normally absorb little or no dietary carbohydrate as hexose sugar, in contrast to milk-fed calves which absorb glucose from the milk sugar lactose. The developmental change in diet at weaning induces a decrease in the $\mathrm{Na}^{+}$-dependent glucose transport activity and in the amount of the $\mathrm{Na}^{+}$-glucose co-transporter present in the intestine (Lescale-Matys et al. 1993). The facilitative glucose transporters probably expressed in the digestive tract of bovines are GLUT1, GLUT5 and GLUT3, since mRNA of these proteins were detected in the duodenal tissue of cows. However, mRNA levels were highest for GLUT1 and lowest for GLUT3 (Zhao et al. 1993). These results are consistent with the ubiquitous expression of GLUT3 in human subjects and the low abundance of GLUT3 mRNA in the duodenum of rodents (for review, see Gould \& Holman, 1993).

\section{Liver}

Since the rate of absorption of hexose sugar from the gut is low, the ruminant liver has little need to remove glucose from the portal blood. Consequently, liver accounts for $0-15 \%$ of the total glucose utilization in sheep $v .25 \%$ in human subjects (for review, see Pethick, 1984). It is well known that the ruminant has adapted to this situation since it has little or no glucokinase (EC 2.7.1.2) and hexokinase activities in the liver. Moreover, the glucose transport rate in hepatocytes of cattle is rather low, about one-third of that of dogs, human subjects and rats (Arai et al. 1992). By contrast, the ruminant liver has a high rate of gluconeogenesis and a net output of glucose even in the fed state. Unlike rats, the rate of gluconeogenesis is directly proportional to digestible energy intake, and more precisely to the availability of glucose precursors in plasma, mainly propionate.

In human, rat and mouse liver, GLUT2 is the primary transporter mediating glucose uptake and release by hepatocytes. As expected, GLUT2 transcripts were detected in 
bovine liver. However, a high level of GLUT5 mRNA was also detected by using a human probe, implying that GLUT5 may be involved also in the uptake and release of glucose in the bovine liver (Zhao et al. 1993). Nevertheless, the presence of GLUT5 in ruminant liver needs to be confirmed with an homologous probe or by immunochemistry.

\section{Erythrocytes}

Bovine erythrocytes were previously known to lack sugar transport systems and sugar transport-related cytochalasin B-binding sites (Lin \& Snyder, 1977), suggesting the absence or a very low level of glucose transporters in bovine erythrocytes. In fact, the entry of glucose into beef erythrocytes was first described by Hoos et al. (1972). Glucose transport into erythrocytes of sheep, cattle and horses is low, about one-third of that in dogs, human subjects and rats (Arai et al. 1992) and about $70 \%$ of that in pigs (Arai et al. 1995). Glucose transport into bovine erythrocytes seems to be mediated by a facilitative transporter of low activity ( $V_{\max }$ about $1 / 2000$ that of the human erythrocyte) and of high affinity $\left(K_{m} 0.09 \mathrm{~mm} \mathrm{v} .4-15 \mathrm{~mm}\right.$ in other species; Hoos et al. 1972). Differences in kinetic and pharmacological variables of glucose transport between bovine erythrocytes and human erythrocytes have been confirmed recently ( $\mathrm{Li}$ et al. 1994). The minimal capacity of bovine erythrocytes to take up glucose may be explained by a very low expression of GLUT1 (at least 1/1000 that in human erythrocytes; Hsu \& Molday, 1991). These results are consistent with a lower rate of glycolysis in ruminant erythrocytes than in erythrocytes from human subjects and dogs (Arai et al. 1995).

Experiments with sheep erythrocytes demonstrated that these cells also possess a facilitated glucose transport system which is dependent on time, concentration and temperature and inhibited by forskolin and cytochalasin B. Sheep erythrocytes were used to study the effect of ginseng extracts on glucose transport rate. The roots of Panax ginseng are well known in Asian countries for a broad spectrum of pharmacological activities and for the treatment of various diseases including diabetes mellitus. The results show that ginseng extracts did stimulate glucose uptake in sheep erythrocytes dose-dependently (Hasegawa et al. 1994). Bovine erythrocytes were also used as a model to study permeability changes (assessed by measurement of nucleosides and glucose transport rate) induced by malarial parasites (Gero et al. 1991).

\section{Vascular cells}

Bovine and human endothelial cells maintained in an atmosphere containing low $\mathrm{O}_{2}$ concentrations up-regulate their glucose transport activity, which is associated with increased GLUT1 protein and mRNA levels (Loike et al. 1992). Glucose transport activity in bovine vascular smooth-muscle cells was about 3 -fold higher than that of bovine aortic endothelial cells, which is related to a higher GLUT1 protein content (Kaiser et al. 1993). Glucose transport rate and GLUT1 expression were decreased in response to chronic hyperglycaemia via translational and/or post-translational mechanisms in bovine smooth cells, but not in endothelial cells (Kaiser et al. 1993). In the same way, high glucose levels $(20 \mathrm{~mm}$ instead of $5 \mathrm{~mm}$ ) down-regulated glucose transport rate in retinal pericytes $(-30 \%)$ but not in retinal endothelial cells. This can be explained, at least in part, by lower expression of immunoreactive GLUT1 in plasma membranes and 
a lower level of GLUT1 mRNA ( $-25 \%$; Mandarino et al. 1994). High glucose levels also induced a decrease in GLUT3 expression in retinal endothelial cells and retinal pericytes with a greater variation being observed in the pericytes (Knott et al. 1993). These results provide evidence that bovine cultured cells may be a good model for studying the regulation of glucose transporters (GLUT1 and GLUT3), especially in hyperglycaemia, which is considered to be a common risk factor for the development of retinopathy and vascular complications in diabetes mellitus. The magnitude of the regulation of the glucose transporters may be lower in endothelial cells than in cells from underlying tissues.

\section{Retinal rods}

Vertebrate rod and cone photoreceptors contain an outer segment which is the site of phototransduction and an inner segment which contains large numbers of mitochondria for energy production. It has been suggested that a phosphocreatine shuttle may serve to channel energy in the form of ATP from the inner segment to the outer segment. Kinetic analysis of hexose influx, efflux and exchange in intact bovine rod outer segments provide evidence that the plasma membrane of these outer segments contains a glucose transporter of the facilitated diffusion type (Hsu \& Molday, 1991; Lopez-Escalera et al. 1991). The presence of the GLUT1 protein was demonstrated by Western-blot analysis and immunofluorescence in the bovine rod outer-segment plasma membrane, but not in disk membranes. The density of GLUT1 in bovine rod outer-segment plasma membrane is of the order of 400-800 v. 1000-2600 transporters/ $\mu \mathrm{m}^{2}$ for human erythrocytes (Hsu \& Molday, 1991; Li et al. 1994). These studies and the presence of glycolytic enzymes suggest that outer segments can directly generate ATP and GTP for phototransduction via anaerobic glycolysis by using glucose as energy source. However, additional energy from the inner segment is needed following photoexcitation (Hsu \& Molday, 1994).

\section{Brain}

The brain accounts for more than $10-15 \%$ of whole-glucose utilization in sheep (Pell \& Bergmann, 1983; Pethick, 1984). Unlike human brain, glucose is the primary energy source for the ovine brain not only in fed animals but also in fasted sheep $\left(90-97 \%\right.$ of $\mathrm{O}_{2}$ uptake by the brain can be accounted for by glucose oxidation in both states; Pell \& Bergmann, 1983). Therefore, the efficiency of glucose transport across the blood-brain barrier is of prime importance. A blood-brain transport system was demonstrated in vivo in adult sheep (Pappenheimer \& Setchell, 1973). Although four facilitative glucose-transporter proteins (GLUT 1,3,5 and 7) have been detected in brain from rodents and human subjects (for review, see Simpson et al. 1994), only the GLUT1 isoform has been studied in bovines since $90-100 \%$ of the glucose transport across the blood-brain barrier is mediated by GLUT1 (for review, see Pardridge \& Boado, 1993).

Glucose transporters were quantified in whole brain either with $\left[{ }^{3} \mathrm{H}\right]$ cytochalasin B or with a radioiodinated derivate of forskolin. Their density is similar in bovine and human brain homogenates (5-12 pmol/mg protein; Robbins et al. 1992). Studies by Northern blot, Western blot, and in situ hybridization provided evidence that the bovine GLUT1 gene is highly expressed at the blood-brain barrier, with minimal expression in neurons or glial cells as in other species. Indeed, the concentration of GLUT1 in purified brain 
microvessels from bovines, rats and human subjects is high (approximately $100 \mathrm{pmol} / \mathrm{mg}$ protein) compared with other brain cells (less than $5 \mathrm{pmol} / \mathrm{mg}$ protein of cell membranes; for review, see Pardridge \& Boado, 1993; Simpson et al. 1994). Despite these differences among brain cells, there are fewer GLUT1 proteins in whole microvessels than in the whole brain, as the microvasculature represents only $2 \%$ of the total brain mass (Simpson et al. 1994). As in rats (for review, see Simpson et al. 1994), bovine GLUT1 proteins in brain capillaries and in choroid plexus differ in their molecular weights which are respectively 54 and $47 \mathrm{kDa}$, with a shift to $42 \mathrm{kDa}$ in both cases following treatment with $\mathrm{N}$-glycanase. This indicates that there is differential processing, presumably of the carbohydrate portion, of the GLUT1 protein in brain cells as opposed to the brain capillary endothelium (Kumagai et al. 1994).

Experiments in vitro with primary cultures of bovine brain microvessel endothelial cells showed that these cells possess a facilitated glucose transport system which is not insulin-sensitive. Paradoxically, the GLUT1 gene is underexpressed by approximately 300-fold in capillary endothelium in tissue culture compared with the expression in vivo (for review, see Pardridge \& Boado, 1993), whereas GLUT1 gene transcription is generally activated in vitro in cultured cells from other tissues (for review, see Klip et al. 1994). This may be due to the absence of brain-derived trophic factors since addition of bovine brain homogenate to the culture medium induces a significant increase in levels of both GLUT1 protein and mRNA and in the transcriptional rate of the bovine GLUT1 gene. These effects are partially mimicked by addition of tumour necrosis factor $\alpha$ (Boado et al. 1994).

The bovine GLUT1 cDNA was cloned from a bovine brain capillary cDNA library screened with a rat GLUT1 probe. The complete bovine GLUT1 mRNA is 2619 nucleotides long, with an open reading frame of 1476 nucleotides encoding a 492-aminoacid protein. Phylogenic analysis of the GLUT1 amino acid and nucleotide sequences revealed that GLUT1 is highly conserved among species (96-98\% identity of deduced amino acids). However, a specific sequence ( $\mathrm{Pro}^{55}-\mathrm{Il}^{56}-\mathrm{Pro}^{57}-\mathrm{Pro}^{58}$ ) was found between predicted transmembrane regions 1 and 2 of the GLUT1 protein in the bovine but not in other species. This proline-rich sequence may confer a specific conformation on the bovine GLUT1 in its N-terminal part. Moreover, this region is contiguous with the predicted single site of $\mathrm{N}$-glycosylation. Thus, paradoxically, an antibody against the $\mathrm{N}$-terminus part of the human GLUT1, which does not react with human GLUT1, does reveal a GLUT1-like protein in microvessels from bovine brain because of this putative specific conformation of the bovine GLUT1 protein. This observation underlines the difficulties of Western-blot analysis and the complexity of immunological studies depending on antibodies, species and protein conformation (for review, see Pardridge \& Boado, 1993).

The $3^{\prime}$ and $5^{\prime}$-untranslated regions of the GLUT1 message also show strong conservation among species. These untranslated sequences may contain potential cis-elements which may react with cytosolic trans-acting factors to control translational efficiency or degradation of the GLUT1 mRNA. These mechanisms seem to be similar in all species studied. There is now evidence that glucose deprivation and development regulate blood-brain barrier GLUT1 gene expression through post-transcriptional mechanisms, possibly involving specific regulatory elements in these untranslated regions (for review, see Pardridge \& Boado, 1993).

Primary cultures of bovine brain microvessel endothelial cells were shown to be a 
valuable model for the study of the regulation of GLUT1-mediated glucose transport at the blood-brain barrier. D-Glucose starvation of cells resulted in a significant increase $(40-70 \%)$ in GLUT1 content and in glucose uptake which was reversible by D-glucose feeding. Glucose deprivation causes an increase in GLUT1 mRNA level which is due, at least in part, to an increase in the half-life of the GLUT1 mRNA (from 3.6 to $6.4 \mathrm{~h}$ ) with no change in transcription rate. Other studies showing that phorbol esters also cause an increase in GLUT1 mRNA levels despite no increase in GLUT1 gene transcription rate provide evidence for post-transcriptional control mechanisms for GLUT1 expression. In contrast, dexamethasone treatment of bovine brain capillary endothelial cells results in a $52 \%$ decrease in GLUT1 mRNA levels probably by a down-regulation of GLUT1 gene transcription (for review, see Pardridge \& Boado, 1993).

\section{Other tissues}

Since it is not always possible to detect glucose-transporter proteins in ruminant tissues because of the lack of any specific antibodies, attempts were made to detect mRNA encoding for these transporters in various bovine tissues. High levels of GLUT1 transcripts were present not only in brain but also in adrenal glands from calves (Hocquette et al. 1996b) and in kidney and mammary gland from lactating cows (Zhao et al. 1993). GLUT1 mRNA were detected in all tissues examined (duodenum, muscular and adipose tissue, kidney, spleen, lung, ovaries) except liver (Zhao et al. 1993; Hocquette et al. 1996b), which is consistent with the ubiquitous tissue distribution of this transporter in other species (for review, see Gould \& Holman, 1993).

GLUT2 mRNA were detected in liver, duodenum and kidney (Zhao et al. 1993), as in other species (for review, see Gould \& Holman, 1993). By contrast, the highest levels of GLUT5 mRNA were in the liver and kidney in the cow (Zhao et al. 1993) and in the small intestine in human subjects (Gould \& Holman, 1993). In the same manner, small amounts of GLUT3 mRNA were observed in bovine mammary gland, skeletal muscles and duodenum (Zhao et al. 1993), in contrast to the ubiquitous distribution of GLUT3 in human tissues and the specific expression of GLUT3 in brain of rodents (Gould \& Holman, 1993). The physiological significance of these differences between bovines and other species is still unknown. Nevertheless, these results need to be confirmed with homologous probes or at the protein level by immunochemistry.

\section{CONCLUSION}

The insulin-sensitive glucose transporter (GLUT4) appears to be a key-protein in the control of glucose uptake and metabolism in ruminant as in single-stomached mammals. However, regulation of GLUT4 expression seems to differ between species: (1) glucose transport rate into muscle cells is positively related to the glycolytic characteristics of the muscle tissue; moreover, oxidative muscles from goats and calves contain a low amount of GLUT4 in contrast to the situation in rats, (2) unlike rodents and human subjects, GLUT4 expression seems to be poorly regulated in bovine adipose tissues since the difference in fat deposition between normal and double-muscled calves is not related to differences in GLUT4 contents in adipocytes, (3) GLUT4 expression is enhanced at weaning in rats but not in bovines which may be due to obvious differences in nutrition among species, (4) a down-regulation of GLUT4 expression was demonstrated in 
muscles from lactating goats which may limit glucose uptake by muscles for the benefit of the mammary gland.

Other species-specific points are the small amount of GLUT4 in subcutaneous adipose tissue and the low glucose transport rates in bovine erythrocytes and hepatocytes (which are likely to be mediated by GLUT1 and GLUT2 respectively). This low glucose uptake potential is consistent with low rates of glycolysis in these tissues.

All these distinctive features of ruminants should limit glucose uptake by oxidative muscles and liver cells, to spare glucose for the benefit of obligatory high-glucoseconsuming tissues or organs (glycolytic muscles, mammary gland in lactating animals, brain). GLUT1 seems to be expressed in the brain at the same level in ruminants as in non-ruminants. It is also noteworthy that bovine GLUT1 is characterized by a specific proline-rich region which may induce a specific conformation of the protein, whose physiological significance is unknown.

Glucose transporters remain to be studied in the ruminant liver which produces, rather than uses, glucose. Unlike other species, the bovine liver seems to express not only GLUT2 but also GLUT5. The physiological role of these transporters in the ruminant liver is still unknown.

For obvious reasons (facilities, size of samples), primary cultures of bovine cells (endothelial, vascular, retinal cells) are interesting models for studying the regulation of facilitative glucose transporters in relation to human diseases (cancer, diabetes-induced retinopathy and vascular complications). However, conclusions for other species should be generalized with caution since striking differences in the regulation of glucose transporters listed previously have been demonstrated between ruminants and nonruminants.

The authors are indebted to F. Bornes, C. Castiglia-Delavaud, N. Depoortere, B. Graulet and N. Guivier (INRA, Theix, France) for their expertise and contributions and to Drs H. Abe (National Institute of Animal Industry, Tsukuba, Japan), N. Lepetit (INSERM U342, Paris, France), Y. Geay, J. Grizard, B. Picard and M. Vermorel (INRA, Theix, France) for helpful discussions.

\section{REFERENCES}

Abe, H., Moritmatsu, M., Aso, H., Shimizu, Y., Nikami, H., Kosaka, K., Syuto, B. \& Saito, M. (1994). Tissue distribution of major insulin-responsive glucose transporter (GLUT4) protein in cattle. Proceedings of the Society of Nutrition Physiology 3, 214.

Abe, H., Moritmatsu, M., Nikami, H., Miyashige, T. \& Saito, M. (1995). Molecular cloning and tissue distribution of bovine insulin-responsive glucose transporter (GLUT4). I $V^{\text {th }}$ International Symposium on the Nutrition of Herbivores, Clermont-Ferrand, France, 11-15 September 1995.

Arai, T., Washizu, T., Sagara, M., Sako, T., Nigi, H., Matsumoto, H., Sasaki, M. \& Tomoda, I. (1995). D-Glucose transport and glycolytic enzyme activities in erythrocytes of dogs, pigs, cats, horses, cattle and sheep. Research in Veterinary Science 58, 195-196.

Arai, T., Washizu, T., Sako, T., Sasaki, M. \& Motoyoshi, S. (1992). D-Glucose transport activities in erythrocytes and hepatocytes of dogs, cats and cattle. Comparative Biochemistry and Physiology 102A, 285-287.

Balage, M., Hocquette, J. F., Graulet, B., Ferré, P. \& Grizard, J. (1994). Insulin-regulatable glucose transporters in skeletal muscles from dry and lactating goats. In Energy Metabolism of Farm Animals, p. 123 [J. F. Aguilera, editor]. Granada, Spain: Consejo Superior de Investigaciones Cientificas.

Balage, M., Sornet, C. \& Grizard, J. (1992). Insulin receptor binding and kinase activity in liver and skeletal muscles of lactating goats. American Journal of Physiology 262, E561-E568. 
Boado, R. J. \& Pardridge, W. M. (1992). Complete protection of antisense oligonucleotides against serum nuclease degradation by an avidin-biotin system. Bioconjugate Chemistry 3, 519-523.

Boado, R. J., Wang, L. \& Pardridge, W. M. (1994). Enhanced expression of the blood-brain barrier GLUT1 glucose transporter gene by brain-derived factors. Molecular Brain Research 22, 259-267.

Brockman, R. P. (1993). Glucose and short-chain fatty acid metabolism. In Quantitative Aspects of Ruminants Digestion and Metabolism, pp. 249-265 [J. M. Forbes and J. France, editors]. Wallingford: CAB International.

Brockman, R. P. \& Laarveld, B. (1986). Hormonal regulation of metabolism in ruminants: a review. Livestock Production Science 14, 313-334.

Burnol, A. F., Leturque, A., Ferré, P., Kande, J. \& Girard, I. (1986). Increased insulin sensitivity and responsiveness during lactation in rats. American Journal of Physiology 251, E537-E541.

Castiglia-Delavaud, C., Hocquette, J. F., Graulet, B., Bornes, F., Lepetit, N. \& Ferré, P. (1996). Insulin-sensitive glucose transporter (GLUT4) transcript levels in calf muscles assessed with a bovine GLUT4 cDNA fragment. The International Journal of Biochemistry and Cell Biology (In the Press).

Debras, E., Grizard, J., Aina, E., Tesseraud, S., Champredon, C. \& Arnal, M. (1989). Insulin sensitivity and responsiveness during lactation and dry period in goats. American Journal of Physiology 256, E295-E302.

Dohm, G. L., Tapscott, E. B., Pories, W. J., Dabbs, D. J., Flickinger, E. G., Meelheim, D., Fushiki, T., Atkinson, S. M., Elton, C. W. \& Caro, J. F. (1988). An in vitro human muscle preparation suitable for metabolic studies. Decreased insulin stimulation of glucose transport in muscle from morbidly obese and diabetic subjects. Journal of Clinical Investigation 82, 486-494.

Elbrink, J. \& Bihler, I. (1975). Membrane transport: its relation to cellular metabolic rates. Glucose transport into animal cells is adapted to their metabolic rate and often controls rates of glucose use. Science 188, $1177-1184$.

Garvey, W. T. (1994). GLUT-4 glucose transporters and insulin action in humans. In Molecular Biology of Diabetes, part 2, pp. 437-471 [B. Draznin and D. Le Roith, editors]. Totowa, NJ: Humana Press Inc.

Gero, A. M., Wood, A. M., Hogue, D. L. \& Upston, J. M. (1991). Effect of diamide on nucleoside and glucose transport in Plasmodium falciparum and Babesia bovis infected erythrocytes. Molecular and Biochemical Parasitology 44, 195-206.

Girard, J., Ferré, P., Pegorier, J. P. \& Duee, P. H. (1992). Adaptations of glucose and fatty acid metabolism during perinatal period and suckling-weaning transition. Physiological Reviews 72, 507-562.

Gould, G. W. \& Holman, G. D. (1993). The glucose transporter family: structure, function and tissue-specific expression. Biochemical Journal 295, 329-341.

Gulve, E. A., Ren, J. M., Marshall, B. A., Gao, J. P., Hansen, P. A., Holloszy, J. O. \& Mueckler, M. (1994). Glucose transport activity in skeletal muscles from transgenic mice overexpressing GLUT1 - increased basal transport is associated with a defective response to diverse stimuli that activate GLUT4. Journal of Biological Chemistry 269, 18366-18370.

Hasegawa, H., Matsumija, S., Murakami, C., Kurokawa, T., Kasai, R., Ishibashi, S. \& Yamasaki, K. (1994). Interactions of ginseng extract separated fractions, and some triterpenoid saponins with glucose transporters in sheep erythrocytes. Planta Medica 60, 153-157.

Henriksen, E. J., Bourey, R. E., Rodnick, K. J., Koranyi, L., Permutt, M. A. \& Holloszy, J. O. (1990). Glucose transporter protein content and glucose transport capacity in rat skeletal muscles. American Journal of Physiology 259, E593-E598.

Hickey, M. S., Carey, J. O., Azevedo, J. L., Houmard, J. A., Pories, W. J., Israel, R. G. \& Dohm, G. L. (1995). Skeletal muscle fiber composition is related to adiposity and in vitro glucose transport rate in humans. American Journal of Physiology 268, E453-E457.

Hocquette, J. F., Bornes, F., Balage, M., Ferré, P., Grizard, J. \& Vermorel, M. (1995). Glucose-transporter (GLUT4) protein content in oxidative and glycolytic skeletal muscles from calf and goat. Biochemical Journal 305, 465-470.

Hocquette, J. F., Bornes, F., Graulet, B., Dardevet, D., Vermorel, M., Geay, Y. \& Ferré, P. (1994). Nutritional regulation of insulin regulatable glucose-transporter in bovine muscle. Reproduction Nutrition Development 34, 628-629.

Hocquette, J. F., Castiglia, C., Ferré, P. \& Vermorel, M. (1996a). Variations in GLUT4 protein content among bovine adipose tissues. Proceedings of the Nutrition Society 55, 21A.

Hocquette, J. F., Graulet, B., Castiglia-Delavaud, C., Bornes, F., Lepetit, N. \& Ferré, P. (1996b). Insulin-sensitive glucose transporter (GLUT4) transcript levels in calf muscles assessed with a bovine GLUT4 cDNA fragment. The International Journal of Biochemistry and Cell Biology (In the Press). 
Hoos, R. T., Tarpley, H. L. \& Regen, D. M. (1972). Sugar transport in beef erythrocytes. Biochimica et Biophysica Acta 266, 174-181.

Hostettler-Allen, R. L., Tappy, L. \& Blum, J. W. (1994). Insulin resistance, hyperglycemia, and glucosuria in intensively milk-fed calves. Journal of Animal Science 72, 160-173.

Hsu, S. C. \& Molday, R. S. (1991). Glycolytic enzymes and a GLUT1 glucose transporter in the outer segments of rod and cone photoreceptor cells. Journal of Biological Chemistry 266, 21745-21752.

Hsu, S. C. \& Molday, R. S. (1994). Glucose metabolism in photoreceptor outer segments. Its role in phototransduction and in NADPH-requiring reactions. Journal of Biological Chemistry 269, 17954-17959.

Hugi, D. P. \& Blum, J. W. (1994). Insulin resistance, hyperglycemia and glucosuria in veal calves: age dependency and effects of lactose supply. Proceedings of the Society of Nutrition Physiology 3, 297.

James, D. E., Strube, M. \& Mueckler, M. (1989). Molecular cloning and characterization of an insulinregulatable glucose transporter. Nature 338, 83-87.

Kaiser, N., Sasson, S., Feener, E. P., Boukobzavardi, N., Higashi, S., Moller, D. E., Davidheiser, S., Przybylski, R. J. \& King, G. L. (1993). Differential regulation of glucose transport and transporters by glucose in vascular endothelial and smooth muscle cells. Diabetes $\mathbf{4 2 , 8 0 - 8 9 .}$

Klip, A., Tsakiridis, T., Marette, A. \& Ortiz, P. A. (1994). Regulation of expression of glucose transporters by glucose - A review of studies in vivo and in cell cultures. FASEB Journal 8, 43-53.

Knott, R. M., Robertson, M. \& Forrester, J. V. (1993). Regulation of glucose transporter (GLUT3) and aldose reductase messenger RNA in bovine retinal endothelial cells and retinal pericytes in high glucose and high galactose culture. Diabetologia 36, 808-812.

Kumagai, A. K., Dwyer, K. J. \& Pardridge, W. M. (1994). Differential glycosylation of the GLUT1 glucose transporter in brain capillaries and choroid plexus. Biochimica et Biophysica Acta 1193, 24-30.

Lescale-Matys, L., Dyer, J., Scott, D., Freeman, T. C., Wright, E. M. \& Shirazi-Beechey, S. P. (1993). Regulation of the ovine intestinal $\mathrm{Na}^{+}$/glucose co-transporter (SLGT1) is dissociated from mRNA abundance. Biochemical Journal 291, 435-440.

Li, X. B., Szerencsei, R. T. \& Schnetkamp, P. P. M. (1994). The glucose transporter in the plasma membrane of the outer segments of bovine retinal rods. Experimental Eye Research 59, 351-358.

Lin, S. \& Snyder, C. E. Jr (1977). High affinity cytochalasin B binding sites to red cell membrane proteins which are unrelated to sugar transport. Journal of Biological Chemistry 252, 5464-5471.

Liu, M. L., Gibbs, E. M., McCoid, S. C., Milici, A. J., Stukenbrok, H. A., McPherson, R. K., Treadway, J. L. \& Pessin, J. E. (1993). Transgenic mice expressing the human GLUT4/muscle-fat facilitative glucose transporter protein exhibit efficient glycemic control. Proceedings of the National Academy of Sciences, USA 90, 11346-11350.

Liu, M. L., Olson, A. L., Moye-Rowley, W. S., Buse, J. B., Bell, G. I. \& Pessin, J. E. (1992). Expression and regulation of the human GLUT4/muscle-fat facilitative glucose transporter gene in transgenic mice. Journal of Biological Chemistry 267, 11673-11676.

Loike, J. D., Cao, L., Brett, J., Ogawa, S., Silverstein, S. C. \& Stern, D. (1992). Hypoxia induces glucose transporter expression in endothelial cells. American Journal of Physiology 263, C326-C333.

Lopez-Escalera, R., Li, X. B., Szerencsei, R. T. \& Schnetkamp, P. P. M. (1991). Glycolysis and glucose uptake in intact outer segments isolated from bovine retinal rods. Biochemistry 30, 8970-8976.

McVeigh, J. M. \& Tarrant, P. V. (1982). Behavioral stress and skeletal muscle glycogen metabolism in young bulls. Journal of Animal Science 54, 790-795.

Mandarino, L. J., Finlayson, J. \& Hassell, J. R. (1994). High glucose downregulates glucose transport activity in retinal capillary pericytes but not endothelial cells. Investigative Ophthalmology and Visual Science 35, 964-972.

Olson, A. L., Liu, M. L., Moye-Rowley, W. S., Buse, J. B., Bell, G. I. \& Pessin, J. E. (1993). Hormonal/metabolic regulation of the human GLUT4/muscle-fat facilitative glucose transporter gene in transgenic mice. Journal of Biological Chemistry 268, 9839-9846.

Pappenheimer, J. R. \& Setchell, B. P. (1973). Cerebral glucose transport and oxygen consumption in sheep and rabbits. Journal of Physiology 233, 529-551.

Pardridge, W. M. \& Boado, R. J. (1993). Molecular cloning and regulation of gene expression of blood-brain barrier glucose transporter. In The Blood-Brain Barrier, pp. 395-440 [W. M. Pardridge, editor]. New York: Raven Press Ltd.

Pell, J. M. \& Bergman, E. N. (1983). Cerebral metabolism of amino acids and glucose in fed and fasted sheep. American Journal of Physiology 244, E282-E289.

Pethick, D. W. (1984). Energy metabolism of skeletal muscle. In Ruminant Physiology. Concepts and Consequences, pp. 277-287 [J. M. Gawthorne, S. K. Baker, J. B. MacKintosh and D. B. Purser, editors]. Nedlands: University of Western Australia. 
Pethick, D. W. (1993). Carbohydrate and lipid oxidation during exercise. Australian Journal of Agricultural Research 44, 431-441.

Picard, B., Hocquette, J. F., Bornes, F., Brazi, S., Vermorel, M. \& Geay, Y. (1994). Muscle metabolism in normal and double-muscled calves: fiber characteristics and glucose transport rate. In Energy Metabolism of Farm Animals, pp. 97-100 [J. F. Aguilera, editor]. Granada, Spain: Consejo Superior de Investigaciones Cientificas.

Prior, R. L., Huntington, G. B. \& Reynolds, P. J. (1984). Role of insulin and glucose on metabolite uptake by the hind half of beef steers. Journal of Animal Science 58, 1446-1453.

Pursel, V. G. \& Rexroad, C. E. Jr (1993). Status of research with transgenic farm animals. Journal of Animal Science 71, Suppl. 3, 10-19.

Ren, J. M., Marshall, B. A., Gulve, E. A., Gao, J. P., Johnson, D. W., Holloszy, J. O. \& Mueckler, M. (1993). Evidence from transgenic mice that glucose transport is rate-limiting for glycogen deposition and glycolysis in skeletal muscle. Journal of Biological Chemistry 268, 16113-16115.

Rizza, R. A., Mandarino, L. J. \& Gerich, J. E. (1981). Dose-response characteristics for effects of insulin on production and utilization of glucose in man. American Journal of Physiology 240, E630-E639.

Robbins, J. D., Appel, N. M., Laurenza, A., Simpson, I. A., Desouza, E. B. \& Seamon, K. B. (1992). Differential identification and localization of adenylyl cyclase and glucose transporter in brain using iodinated derivatives of forskolin. Brain Research 581, 148-152.

Roehrig, K., Nestor, K. E. Jr \& Palmquist, D. L. (1988). ATP citrate lysase activity in liver and adipose tissue of veal or ruminating calves (Bos taurus). Comparative Biochemistry and Physiology 90B, 147-149.

Sano, H., Nakai, M., Kondo, T. \& Terashima, Y. (1991). Insulin responsiveness to glucose and tissue responsiveness to insulin in lactating, pregnant, and nonpregnant, nonlactating beef cows. Journal of Animal Science 69, 1122-1127.

Sasaki, S. (1990). Mechanism of insulin resistance in the post receptor events in sheep. Hormone Metabolic Research 22, 457-461.

Schultz, G. A., Hogan, A., Watson, A. J., Smith, R. M. \& Heyner, S. (1992). Insulin, insulin-like growth factors and glucose transporters: temporal patterns of gene expression in early murine and bovine embryos. Reproduction Nutrition and Fertility 4, 361-371.

Simpson, I. A., Vannucci, S. J. \& Maher, F. (1994). Glucose transporters in mammalian brain. Biochemical Society Transactions 22, 671-675.

Swinburn, B. A., Nyomba, B. L., Saad, M. F., Zurio, F., Raz, I., Knowler, W. C., Lillioja, S., Bogardus, C. \& Ravussin, E. (1991). Insulin resistance associated with lower rates of weight gain in Pima indians. Journal of Clinical Investigation 88, 168-173.

Takata, K., Kasahara, M., Oka, Y. \& Hirano, H. (1993). Mammalian sugar transporters - their localization and link to cellular functions. Acta Histochemica et Cytochemica 26, 165-178.

Trayhurn, P., Thomas, M. E. A. \& Keith, J. S. (1993). Postnatal development of uncoupling protein, uncoupling protein messenger RNA, and GLUT4 in adipose tissues of goats. American Journal of Physiology 265, R676-R682.

Vernon, R. G., Faulkner, A., Finley, E., Pollock, H. \& Taylor, E. (1987). Enzymes of glucose and fatty acid metabolism of liver, kidney, skeletal muscle, adipose tissue and mammary gland of lactating and non-lactating sheep. Journal of Animal Science 64, 1395-1411.

Wheeler, T. J. \& Hauck, M. A. (1985), Reconstitution of the glucose transporter from bovine heart. Biochimica et Biophysica Acta 818, 171-182.

Zhao, F. Q., Glimm, D. R. \& Kennelly, J. J. (1993). Distribution of mammalian facilitative glucose transporter messenger RNA in bovine tissues. International Journal of Biochemistry 25, 1897-1903.

Ziel, F. H., Venkatesan, N. \& Davidson, M. B. (1988). Glucose transport is rate limiting for skeletal muscle glucose metabolism in normal and STZ-induced diabetic rats. Diabetes 37, 885-890. 